Arch. Tierz., Dummerstorf 47 (2004) 1, 37-46

Research Institute of Animal Production, Nitra, Slovakia

JAN BROUCEK, STEFAN MIHINA, MICHAL UHRINCAT, PETER KISAC, ANTON HANUS and VLADIMIR TANCIN

\title{
The effect of sire line on growth, ambulating in novel environment and maze learning in heifers
}

\begin{abstract}
The aim of this study was to investigate the influence of sire's lineage on live body growth, movement in openfield arena and time of acrossing the maze of heifers. 54 Holstein heifers, which descended from 7 sires, were used. The highest growth from the birth to 21 months was found in the progeny of sire $\mathrm{D}$, the lowest growth in daughters of sire line B $(0.74 \pm 0.05 \mathrm{~kg}$ vs. $0.62 \pm 0.08 \mathrm{~kg} ; \mathrm{P}<0.01)$. Number of crossed squares in open-field tests did not vary significantly among sire lines. Significant differences were found among sires in the time across of the maze $(\mathrm{P}<0.01)$. Daughters after $\mathrm{F}$ and $\mathrm{E}$ sires solved the maze more quickly then the others. We found significant relationships between a number of crossed squares during 5 minute open-field test and daily weight gains from the birth to the $6^{\text {th }}$ month of life $\left(\mathrm{r}=0.3712^{* *}\right.$ at the age of 16 weeks and $\mathrm{r}=0.3792^{* *}$ at the age of 18 months). Under consideration of the low number of animals analyses showed, that sire's lineage has impact on the growth and maze behaviour.
\end{abstract}

Key Words: dairy heifers, sire, growth, behaviour, temperament, open-field test

\section{Zusammenfassung}

Titel der Arbeit: Einfluss der väterlichen Linie auf Wachstum, Bewegungsverhalten in neuer Umgebung und Lernen im Labyrinth bei Färsen

Ziel dieser Studie war die Untersuchung des Einflusses der väterlichen Linie auf die Lebendgewichtszunahme, das Bewegungsverhalten im Open-Field Test und das Lernverhalten als Zeit des Laufens im Labyrinth bei weiblichen Jungrindern. Einbezogen waren 54 Holstein-Friesian Färsen von Vätern aus sieben Bullenlinien. Sowohl in der Gewichtsentwicklung bis 21 Monate als auch in den einzelnen Kontrollabschnitten bis zum Alter von 21 Monaten unterschieden sich die Töchtergruppen signifikant. Keine signifikanten Unterschiede konnten in der Anzahl Quadratüberquerungen im Open-Field Test nachgewiesen werden. Bezüglich des Lernverhaltens durchquerten einzelne Töchtergruppen das Labyrinth schneller als andere Bullennachkommen. Unter Berücksichtigung der relativ geringen Tierzahl konnte festgestellt werden, dass die väterliche Linie sowohl das Wachstum als auch das Lernverhalten der Färsen beeinflusste.

Schlüsselwörter: Färsen, Väter, Wachstum, Verhalten, Temperament, Open-Field Test

\section{Introduction}

The use of modern dairy management methods instead of the conventional technology needs cows resistant to stress and able to adapt to altered conditions of environment in coherence with new procedures with automated feeding and robotization of milking. Failure to adapt can lead to chronic distress. Many features related to behaviour and performance, are extremely sensitive to genetic selection. Experiments on cattle have shown an interaction between genetic and environmental factors (SOCH et al., 1998). The differences in behaviour of individual cattle breeds and gender are known (SAMBRAUS, 1998; GAULY et al., 2001a). The differences within the breed are less explored. Bulls can produce daughters which are aggressive towards humans in range 
conditions, whereas other daughters are easy to handle in intensive systems (LE NEINDRE et al., 1996).

Reaction of cattle in an unknown environment is influenced by temperament. Temperament can be defined as how an individual reacts to novel or challenging situations (REALE et al., 2000). There are used many methods for temperament measuring (BURROW, 1997). Animals that are calm and docile during handling are evaluated to have good temperaments, while those that are nervous and flighty are said to have poor temperaments. Each of the various tests measures different behaviours. Flight speed scores were moderately to highly heritable $(0.40-0.44)$. Genetic and phenotypic relationships between flight speed scores and most other traits indicated that, under extensive management systems, temperament is largely an independent trait (BURROW, 2001). Temperament has been shown to be a heritable trait (PETHERICK et al., 2002), but also experiences are known to influence it (BURROW, 1997). SATO (1981) estimated heritability of temperament from the observed resemblance of daughters to their dams (0.67).

The genetic influences on behaviour can be clearly manifested by the study of influence of sires (KUBEK et al., 2000; SOCH et al., 1997). The sire influences a large part of the population so its genetic qualities are effective as a stabilisation factor. DICKSON et al. (1970) found out that father has significant influence on behaviour of daughters in the milking parlour and on their temperament. They used of 31 sires with four or more daughters. The estimate of heritability for temperament score was 0.53 .

Behavioural traits related to the temperament were studied and the genetic variability of these parameters were estimated by GAULY et al. (2001b). The heritability for the temperament were between 0.0 and 0.61 for German Angus and, 0.0 and 0.59 for Simmental cattle. Traits negatively correlated with daily weight gain.

FELL et al. (1999) selected steer calves on the basis of their flight time and crush behaviour into 2 groups - nervous and calm. The nervous group had significantly lower average daily gain and significantly higher morbidity than calm group. Significant correlation's were found between flight time and average daily gain. According to BURROW (2001), the genetic and phenotypic correlation's between flight speed scores and weights and period weight gains between birth and 18 months were all close to zero. Temperament scores evaluated by VOISINET et al., (1997 b) showed that increased temperament score resulted in significantly decreased average daily gains. Cattle which were quieter and calmer during handling had greater average daily gains than cattle that became agitated during routine handling.

The motoric activity belongs to the most typical behavioural manifestations in contact with the unknown environment. Therefore the open-field test be can used as an objective ethological method for the temperament measuring. Of course the size of reaction can be influenced by factors of environment and present psychical and physiological state of the animal (KILGOUR, 1975). BÜNGER and KAPHENGST (1987) found that locomotor behaviour of calves in open-field arena was significant affected by housing. Significant differences of locomotor behaviour were found in evaluation of four genetic sire lines (KOVALCIKOVA et al., 1988).

The learning ability means how is an animal able to change its behaviour to cope better with environmental circumstances. The maze learning is a type of operating conditioning, behaviour is the instrument by which the reinforcement is obtained (HOUPT, 1991). The speed and correctness of an animal in running through various 
types of mazes has long been used as a measure of animal intelligence and learning ability (ALBRIGHT and ARAVE, 1997). Social deprivation can to change orienting behaviour, exploration, play or learning ability. FRANZ (1999) determined the influence of social deprivation on learning success in calves socially deprived before testing. Calves tested in groups performed better than calves tested in isolation.

Genetic differences may affect the learning ability of different strains within a species. ARAVE et al. (1992) proved that Holstein heifers of some sires showed higher level of activity and better ability to learn in the maze. In experiments discussed in review of HOHENBOKEN (1987) with respect to breed differences in learning ability of pigs, estimated heritabilities of the measure of learning ability were 0.45 and 0.52 . Results suggested that neither prenatal nor postnatal maternal effects, nor dominance effects of genes were important determinants of avoidance learning behaviour.

The objective in this study was to determine whether sire line of heifers influences their growth, excitability in unknown arena open-field test and speed of solving the path in the maze.

\section{Materials and methods}

We used 54 Holstein heifers which originated from 7 sires (A, $n=11 ; B, n=7 ; C, n=15$; $D, n=4 ; E, n=9 ; F, n=3 ; G, n=5)$. They were reared in individual hutches till weaning. The weaning was carried out for all animals at the age of 8 weeks. All heifers were kept after weaning in common loose housing pens (in the same barn) according to age and size until $21^{\text {st }}$ month.

Calves were drinked from the eighth day $6 \mathrm{~kg}$ of milk replacer per day from a bucket with nipple divided into 2 portions in $12 \mathrm{~h}$ intervals. The calves could eat starter mixtures and alfalfa hay in free choice until weaning. They received $1,5 \mathrm{~kg}$ of concentrate mixture per day and alfalfa hay offered free choice from weaning to 180 days. From the age of 90 days they got also corn silage. From 181st day, all heifers were fed the same diet according to Slovakian recommendations for intake of dry matter to attain $0.75 \mathrm{~kg}$ average daily gain. The total mixed ration contained alfalfa hay, corn silage, concentrate mixture and mineral/vitamins supplements. Water was provided for ad libitum intake at all times.

At the birth and every 30 days, weight gain assessment data were recorded for all heifers.

An open-field test was applied at two ages: A1 (4 months) and A2 (18 months) in an arena marked off into 9 squares. In A1, the size of arena was $4.5 \times 4.5 \mathrm{~m}$, at the A2 age $10 \times 10 \mathrm{~m}$. The calves were given one 5-minutes test (morning). The animals were exposed to isolation and silence. Three parameters were recorded by a video camera: numbers of squares entered during ambulating, numbers of vocalisation and defecation.

The maze learning ability tests were performed in the 6-unit maze 16.4 x $4.5 \mathrm{~m}$ at the age of 15 weeks. Five barriers were installed inside which marked the beginning and the end of the route and also particular parts of the maze. In the exit part a bucket with feed mixture was placed. The calf was allowed to eat for only a few seconds, whereupon it was led out of the maze to repeat the procedure. Time was recorded from the moment of the entry to the exit. The calves had to solve two tasks on two consecutive days. On the first observation day (first task), the calves were tested five times, three runs in the morning and two runs in the afternoon. The first test was for 
training. On the second day (second task), there were two runs in the morning and two runs in the afternoon. In the first task, the passage was open on the left side, and on the right side (second task) on the next day.

The data were analysed with a statistical package Statistix for Windows (1996). The normal distribution of data was evaluate by Wilk-Shapiro/Rankin Plot procedure. Between-group comparisons of growth traits and ambulating in open-field tests were analysed using a General linear model analysis of variance (General AOV/AOCV). Significant differences between means were tested by Bonferroni's test. Since data of time traversing the maze had not normal distribution we used Kruskal-Wallis analysis of variance for evaluation. Pearson Correlation was used for relationship between locomotor behaviour in the open-field tests and growth traits. Relationships between growth and time traversing the maze were calculated by Spearman correlation`s.

Table 1

Live body weight in individual sire line

\begin{tabular}{|c|c|c|c|c|c|}
\hline Sir & $\mathrm{N}$ & Birth & 180 days & 360 days & 540 days \\
\hline A & 11 & $39.36 \pm 5.88$ & $173.71 \pm 23.70$ & $309.98 \pm 30.45$ & $425.09 \pm 42.30$ \\
\hline B & 7 & $44.86 \pm 3.80$ & $163.21 \pm 10.12$ & $304.20 \pm 21.72$ & $390.24 \pm 35.24$ \\
\hline $\mathrm{C}$ & 15 & $41.27 \pm 4.96$ & $161.97 \pm 13.46$ & $318.69 \pm 18.49$ & $419.95 \pm 23.60$ \\
\hline $\mathrm{D}$ & 4 & $46.00 \pm 5.10$ & $166.12 \pm 27.15$ & $353.08 \pm 15.54$ & $456.93 \pm 27.21$ \\
\hline $\mathrm{E}$ & 9 & $39.00 \pm 1.80$ & $178.96 \pm 16.87$ & $304.82 \pm 34.21$ & $433.52 \pm 24.27$ \\
\hline $\mathrm{F}$ & 3 & $43.00 \pm 5.57$ & $188.17 \pm 8.49$ & $319.83 \pm 29.20$ & $434.80 \pm 48.15$ \\
\hline G & 5 & $39.20 \pm 5.54$ & $164.62 \pm 27.18$ & $321.50 \pm 50.87$ & $440.52 \pm 47.78$ \\
\hline F value & & 2.17 & 1.60 & 1.66 & 2.19 \\
\hline \multirow{2}{*}{\multicolumn{2}{|c|}{ Significance }} & $\mathrm{D}: \mathrm{A}, \mathrm{G}, \mathrm{E}^{* *}$ & $\mathrm{~F}: \mathrm{C}^{* *}$ & $\mathrm{D}: \mathrm{A}, \mathrm{E}, \mathrm{B}^{* *}$ & $\mathrm{D}: \mathrm{B}^{* * *} ; \mathrm{G}: \mathrm{B}^{* *}$ \\
\hline & & $\mathrm{B}: \mathrm{G}, \mathrm{E}^{*}$ & $\mathrm{~F}: \mathrm{D}, \mathrm{G}, \mathrm{B}^{* *}$ & $\mathrm{D}: \mathrm{C}^{* *}$ & $\mathrm{~F}, \mathrm{E}: \mathrm{B}^{* *}$ \\
\hline Nonadditivity & & 0.05 & 0.11 & 3.09 & 0.17 \\
\hline
\end{tabular}

Table 2

Average daily gains in individual sire line

\begin{tabular}{|c|c|c|c|c|c|}
\hline Sir & $\mathrm{N}$ & Birth-6 months & Birth-21 months & 6-12 months & 6-21 months \\
\hline A & 11 & $0.75 \pm 0.12$ & $0.69 \pm 0.08$ & $0.76 \pm 0.17$ & $0.66 \pm 0.12$ \\
\hline B & 7 & $0.66 \pm 0.05$ & $0.62 \pm 0.08$ & $0.78 \pm 0.10$ & $0.61 \pm 0.11$ \\
\hline $\mathrm{C}$ & 15 & $0.67 \pm 0.08$ & $0.68 \pm 0.05$ & $0.87 \pm 0.06$ & $0.68 \pm 0.06$ \\
\hline $\mathrm{D}$ & 4 & $0.66 \pm 0.17$ & $0.74 \pm 0.05$ & $1.04 \pm 0.09$ & $0.77 \pm 0.06$ \\
\hline $\mathrm{E}$ & 9 & $0.76 \pm 0.09$ & $0.70 \pm 0.04$ & $0.71 \pm 0.15$ & $0.67 \pm 0.08$ \\
\hline $\mathrm{F}$ & 3 & $0.80 \pm 0.05$ & $0.68 \pm 0.07$ & $0.72 \pm 0.12$ & $0.63 \pm 0.08$ \\
\hline G & 5 & $0.69 \pm 0.15$ & $0.73 \pm 0.06$ & $0.87 \pm 0.17$ & $0.75 \pm 0.09$ \\
\hline F value & & 1.89 & 2.28 & $4.39^{* *}$ & 2.12 \\
\hline Significance & & $\mathrm{F}: \mathrm{C}, \mathrm{D}, \mathrm{B}^{*}$ & $\begin{array}{l}\mathrm{D}, \mathrm{G}: \mathrm{B}^{* *} \\
\mathrm{E}: \mathrm{B}^{*}\end{array}$ & $\begin{array}{l}\mathrm{D}: \mathrm{B}, \mathrm{A}, \mathrm{F}, \mathrm{E}^{* * *} \\
\mathrm{D}: \mathrm{G}, \mathrm{C}^{*} \\
\mathrm{G}, \mathrm{C}: \mathrm{E}^{*}\end{array}$ & $\begin{array}{l}\mathrm{D}: \mathrm{B}^{* * *} ; \mathrm{D}: \mathrm{F}^{* *} \\
\mathrm{G}: \mathrm{B}^{* *} ; \mathrm{G}: \mathrm{F}^{*}\end{array}$ \\
\hline Nonadditivity & & 0.02 & 0.69 & 0.94 & 0.49 \\
\hline
\end{tabular}




\section{Growth}

\section{Results}

The most intensive growth of live body weight was found in the progeny of sire D in comparison with daughters of six others sires. These animals had the significantly highest live body weight at birth and also at the ages of 360 and 540 days (Table 1). The average daily gains in the period from birth to 21 months, from 6th to 12th month and from 6th to 21st month, were significantly highest in this group of heifers (Table 2). The least intensive growth of live body weight and also the lowest daily gains were found in a group of daughters of sire line B.

\section{Ambulating}

Locomotor behaviour in the open-field test did not vary among daughters of the observed sires at the age of 16 weeks; significant differences were found only in a mutual comparison of individual groups of daughters (Table 3). Interaction among groups was found only in the number of crossed squares in the first minute of the test (nonadditivity $6.52^{*}$ ). Daughters of sire A crossed the most squares in 5 minutes of the test (48.6) and daughters of sire $\mathrm{C}$ the fewest (33.8).

At the age of 18 months, a significant difference among groups of daughters in the number of crossed squares was found in the 3rd minute only $(* \mathrm{P}<0.05)$. Nonadditivity was significant in the evaluation of the number of crossed squares in 5 minutes of the open-field test $(* \mathrm{P}<0.05)$.

Table 3

Number of crossed squares during open-field test

\begin{tabular}{|c|c|c|c|c|c|}
\hline \multirow[t]{2}{*}{ Sir } & \multirow[t]{2}{*}{$\mathrm{n}$} & \multicolumn{2}{|c|}{ The age of 4 months } & \multicolumn{2}{|c|}{ The age of 18 months } \\
\hline & & $1^{\text {st }}$ minute & 5 minutes & $1^{\text {st }}$ minute & 5 minutes \\
\hline A & 11 & $17.6 \pm 7.5$ & $48.6 \pm 22.1$ & $6.4 \pm 3.3$ & $33.3 \pm 18.8$ \\
\hline B & 7 & $10.3 \pm 5.9$ & $46.6 \pm 23.9$ & $8.4 \pm 3.2$ & $41.6 \pm 5.9$ \\
\hline $\mathrm{C}$ & 15 & $12.6 \pm 4.4$ & $33.8 \pm 13.6$ & $7.1 \pm 2.5$ & $32.7 \pm 11.4$ \\
\hline $\mathrm{D}$ & 4 & $15.5 \pm 8.8$ & $45.7 \pm 24.1$ & $9.0 \pm 7.1$ & $29.7 \pm 10.7$ \\
\hline $\mathrm{E}$ & 9 & $13.5 \pm 5.8$ & $40.0 \pm 19.8$ & $9.5 \pm 5.4$ & $35.9 \pm 16.0$ \\
\hline F & 3 & $9.7 \pm 4.2$ & $36.7 \pm 13.2$ & $10.3 \pm 9.3$ & $50.7 \pm 24.6$ \\
\hline G & 5 & $15.2 \pm 9.1$ & $45.4 \pm 29.9$ & $10.0 \pm 4.9$ & $40.2 \pm 23.0$ \\
\hline \multicolumn{2}{|c|}{ F value } & 1.40 & 0.74 & 0.85 & 0.93 \\
\hline \multicolumn{2}{|c|}{ Significance } & $\mathrm{A}: \mathrm{F}^{*}$ & & & $\mathrm{~F}: \mathrm{D}^{*}$ \\
\hline \multicolumn{2}{|c|}{ Nonadditivity } & $6.52^{*}$ & 1.56 & 0.04 & $4.54^{*}$ \\
\hline
\end{tabular}

\section{Maze behaviour}

During the first four tests, when the maze was open to the left side, the fastest calves were those of the D sire and the slowest those of sires E and F (Table 4). The second day, after changing the configuration of the maze by opening a passage to the right side (second task), the times of traversing the maze in comparison with task $\mathrm{A}$ increased. The previous trend was maintained, calves of the D sire were traversing towards the goal the fastest and those of sires $\mathrm{E}$ and $\mathrm{F}$ the slowest. There were significant differences among daughters of the observed sires. According to a total evaluation of the average time of traversing the maze in all eight tests, we can divide 
heifers, based on a Kruskal-Wallis analysis of variances (Table 4), into two different groups - daughters of sires F, E and the others (daughters of sires C,G,A,B and D).

Table 4

Average times of traversing the maze (s)

\begin{tabular}{|c|c|c|c|c|}
\hline Sir & $\mathrm{n}$ & $1^{\text {st }}$ task & $2^{\text {nd }}$ task & Total \\
\hline A & 11 & $202.9 \pm 201.8$ & $289.2 \pm 168.1$ & $492.1 \pm 337.2$ \\
\hline $\mathrm{B}$ & 7 & $136.7 \pm 73.0$ & $240.6 \pm 135.3$ & $377,3 \pm 179.9$ \\
\hline $\mathrm{C}$ & 15 & $200.7 \pm 119.1$ & $442.7 \pm 282.9$ & $643.3 \pm 368.2$ \\
\hline $\mathrm{D}$ & 4 & $83.7 \pm 51.9$ & $168.7 \pm 61.0$ & $252.5 \pm 110.9$ \\
\hline $\mathrm{E}$ & 9 & $491.9 \pm 328.4$ & $679.6 \pm 336.5$ & $1171.4 \pm 469.6$ \\
\hline $\mathrm{F}$ & 3 & $442.7 \pm 353.6$ & $797.0 \pm 596.9$ & $1239.7 \pm 947.4$ \\
\hline G & 5 & $219.2 \pm 202.5$ & $277.2 \pm 112.3$ & $496.4 \pm 134.4$ \\
\hline F value & & $3.33^{* *}$ & $3.41 * *$ & $4.16^{* *}$ \\
\hline Significance & & n.s. & $E: D^{*}$ & $\mathrm{E}: \mathrm{B}, \mathrm{D}^{*}$ \\
\hline
\end{tabular}

\section{Relationships}

We found significant relationships (Tab. 5) between a number of crossed squares during 5 minute open-field test and daily weight gains from the birth to the $6^{\text {th }}$ month of life ( $\mathrm{r}=0.3712^{* *}$ at the age of 16 weeks and $\mathrm{r}=0.3792^{* *}$ at the age of 18 months). Daughters of D and B fathers showed the most uniform relationships between the number of crossed squares during the first minute of open-field tests at the ages of 16 weeks and 18 months and live body weight at the birth and 540 days. Group D had all correlation's positive and mostly high ( $\mathrm{r}=0.8234, \mathrm{r}=0.2625$ and $\mathrm{r}=0.7164, \mathrm{r}=0.6186)$, group B had all relationships negative and high $(\mathrm{r}=-0.3167, \mathrm{r}=-0.6232$ and $\mathrm{r}=-0.0761$, $\mathrm{r}=-0.7118$ ). Relationships between live body weight and locomotor behaviour were again always positive in sire line $\mathrm{D}$ in the evaluation of all 5 minutes of the test in both ages $(\mathrm{r}=0.3505, \mathrm{r}=0.4596$ and $\mathrm{r}=0.3232, \mathrm{r}=0.8231)$.

Table 5

Phenotypic correlation's between the number of crossed squares and growth traits

\begin{tabular}{lcrcc}
\hline \multirow{2}{*}{ Age } & \multicolumn{2}{c}{ Live body weight } & \multicolumn{2}{c}{ Daily weight gains } \\
& Birth & 540 days & Birth -6 months & Birth -21 months \\
\hline 4 months & 0.0694 & 0.0789 & $0.3712^{* *}$ & -0.0503 \\
18 months & -0.0207 & 0.1976 & $0.3792^{* *}$ & 0.1432 \\
\hline$* * \mathrm{P}<0.01$ & $\mathrm{n}=54$ & &
\end{tabular}

Correlation's between a maze behaviour and growth traits were weak in the entire set of 54 heifers. High and always positive relationships (Tab. 6) were between the total time of traversing the maze and live body weight at birth and at the age of 540 days in the group $\mathrm{F}(\mathrm{r}=0.9980$ and $\mathrm{r}=0.5000)$. Negative and higher correlation's were found in groups $\mathrm{C}\left(\mathrm{r}=-0.4996^{*}, \mathrm{r}=-0.5679^{*}\right)$ and $\mathrm{D}(\mathrm{r}=-0.8000, \mathrm{r}=-0.4000)$. 
Table 6

Phenotypic correlation's between total time traversing the maze and growth traits

\begin{tabular}{|c|c|c|c|c|c|}
\hline \multirow[t]{2}{*}{ Sir } & \multirow[t]{2}{*}{$n$} & \multicolumn{2}{|c|}{ Live body weight } & \multicolumn{2}{|c|}{ Daily weight gains } \\
\hline & & Birth & 540 days & Birth - 6 months & Birth - 21 months \\
\hline A & 11 & 0.4521 & 0.1636 & -0.0046 & 0.0274 \\
\hline B & 7 & 0.3604 & 0.2143 & -0.6847 & 0.3694 \\
\hline $\mathrm{C}$ & 15 & $-0.4996 *$ & $-0.5679 *$ & -0.1512 & -0.0700 \\
\hline $\mathrm{D}$ & 4 & -0.8000 & -0.4000 & 0.0000 & -0.4000 \\
\hline $\mathrm{E}$ & 9 & $-0.6211^{*}$ & $0.6667 *$ & 0.4184 & 0.2979 \\
\hline $\mathrm{F}$ & 3 & 1.0000 & 0.5000 & -0.5000 & -0.5000 \\
\hline G & 5 & -0.1000 & -0.1000 & -0.3000 & 0.5000 \\
\hline
\end{tabular}

\section{Discussion}

The lower growth rate and reduced meat quality are associated with greater reactivity of animals during handling as indicated by their crush chute score (VOISINET et al., 1997 a,b) and by faster flight times (BURROW and DILLON, 1997). PETHERICK et al. (2002) found that cattle with poor temperament had poorer average daily gains, feed conversion efficiencies and body conditions compared with those with good temperaments. Reduced performance in the poor-temperament animals may have resulted from their fearfulness and state of high arousal. Situations of uncertainty, social pressure and fear are potent stressors with relevance for the well-being of animals (VON BORELL, 2000).

In a number of studies, temperament, measured in a variety of ways, has been found to be correlated with improved production (VOISINET et al. 1997 a; FELL et al. 1999). In our study, heifers of sire A crossed the most squares in 5 minutes at the age of 16 weeks and heifers of sire $\mathrm{C}$ the fewest. If line $\mathrm{A}$ had worse temperament and line $\mathrm{C}$ better, the relationship between GC and daily gain would be significantly different. In fact, there were high and positive correlation's in both lines in the period from birth to 180 days. Excitability evaluated by locomotor behaviour is probably not comparable with temperament in Holstein heifers.

We decided for a standard behavioural method which measures reactivity during social isolation and is commonly used to measure general fearfulness as well. Observers' ratings may provide information on this aspect, but open-field test facilitates the comparison of individuals in a standardised way (KAPHENGST and BÜNGER, 1988; MANTECA and DEAG, 1993). It is expected that individuals which orientates themselves quickly and behave calm during the open-field tests will react calmly in other non-model situations which arise during their life. However, we did not obtain sufficient proofs about behaviour of our observed animals in open-field tests. The differences among sire lines were no significant and relationships to growth traits were with the exceptions of lines B and D moderate or close to zero. The problem lies probably in a suitable method of testing, because temperament is mostly determined as the animal's flight speed or the restraint test. It is also possible that the Holstein breed animals are not easy to evaluate because of their very docile temperament and discipline. As discussed by BURROW (1997), a major difficulty with these tests is that we are unsure as to what is actually being assessed. Animals 
differ in reacting to being socially isolated, being in an unfamiliar place, confined, restrained or close proximity to people. Different ethological tests could give different results depending on which of these factors are incorporated into the test situation. Animal behaviour is probably influenced by emotional standards much more then was anticipated (PUPPE, 1996). The ability of animals to cope with environment is a prerequisite for fitness, which means that is very important in this issue of the effects of the sire line.

Animals with poor temperaments continued to have poor temperaments, while those with good temperaments maintained their good temperament (PETHERICK et al., 2002). In our trial, the durability of ambulating behaviour were not maintained throughout rearing. In the first test at the age of 16 weeks, heifers from line A were the most moveable and heifers from line $\mathrm{F}$ the least moveable. On the contrary, in the other observation 14 months later on, the most movable was group F, and group A was one of the least mobile sire lines. This suggests a low repeatability between numbers of crossed squares at the ages of 16 weeks and 18 months. We, therefore, suppose that the maintenance of a comparable trend of the ambulating activity need not be a result of animal temperament, but a result of the repeated handling process. It is possible, that changes to temperament may occur in animals learning from others over a long period of time.

When planning this trial, we assumed that the most important results of behaviour will be obtained in the open-field test. To our surprise, conclusions from the evaluation of learning were much more significant. We opted for the maze test, which is used in research on the orientation and memory of animals. The our results proved highly significant differences among sires in learning ability of their daughters measured by the time of acrossing the maze, similarly to the work of ARAVE et al. (1992). These authors evaluated data of 181 calves from 17 sire lines (with 3 or more calves). A sire effect on learning ability was evident, sire significantly affected maze activity scores. Results substantiated that calves can manoeuvre through a fairly complex maze and their ability has a definite genetic component (sire effect).

\section{Conclusion}

We can conclude that impact of the sire line has been proven on the growth and maze behaviour of dairy heifers. We did not find the effect of sire line on locomotor activity in open-field tests. For further research, it would be necessary to compare the findings with the study on Holstein males.

\section{References}

ALBRIGHT, J.L.; ARAVE, C.W.:

The Behaviour of Cattle. CAB International, (1997), $299 \mathrm{p.}$

ARAVE, C.W.; LAMB, R.C.; ARAMBEL, M.J.; PURCELL, D.; WALTERS, J.L.:

Behavior and maze learning ability of dairy calves as influenced by housing, sex and sire. Appl. Anim. Behav. Sci. 33 (1992), 149-163

BORELL, E. v.:

Mechanismen der Bewältigung von Stress. Arch. Tierz., Dummerstorf 43 (2000), 441-450

BÜNGER, U.; KAPHENGST, P.:

Zum Verhalten von Tränkkälbern in einer fremdartigen Umwelt. Mh. Vet. Med. 42 (1987), 378-383

BURROW, H.M.:

Measurements of temperament and their relationships with performance traits of beef cattle. Animal Breeding Abstracts. 65 (1997), 477-495 
BURROW, H.M.; DILLON, R.D.:

Relationships between temperament and growth in a feedlot and commercial carcass traits of Bos indicus crossbreds. Austral. J. Experim. Agric. 37 (1997), 407-411

BURROW, H.M.:

Variances and covariances between productive and adaptive traits and temperament in a composite breed of tropical beef cattle. Livest. Prod. Sci. 70 (2001), 213-233

DICKSON, D.P.; BARR, G.R.; JOHNSON, L.P.; WIECKERT, D.A.:

Social dominance and temperament in dairy cows. J. Dairy Sci. 53 (1970), 904-907

FELL, L.R.; COLDITZ, I.G.; WALKER, K.H.; WATSON, D.L.:

Associations between temperament, performance and immune function in cattle entering a commercial feedlot. Austral.J. Experim. Agric. 39 (1999), 795-802

FRANZ, H.:

Methode zur Untersuchung der Lernfähigkeit von Kälbern in Gruppenhaltung und Ergebnisse bei visuellen Differenzierungsaufgaben. Arch. Tierz., Dummerstorf 42 (1999), 241-254

GAULY, M.; MATHIAK, H.; KRAUS, M.; HOFFMANN, K.; ERHARDT, G.:

Rasse- und Geschlechtsunterschiede im Temperament von Kälbern in Mutterhaltung. Dtsch. tierärztl. Wschr. 108 (2001a), 206-210

GAULY, M.; MATHIAK, H.; HOFFMANN, K.; KRAUS, M.; ERHARDT, G.:

Estimating genetic variability in temperamental traits in German Angus and Simmental cattle. Appl. Anim. Behav. Sci. 74 (2001b), 109-119

HOHENBOKEN, W.D.:

Behavioral genetics. Vet. Clin. of North Am.: Food Animal Practice. 3 (1987), 217-229

HOUPT, K.A.:

Domestic Animal Behavior for veterinarians and animal scientists. Iowa State University Press, Ames, Iowa 50014, (1991), 408 p.

KAPHENGST, P.; BÜNGER, U.:

KILGOUR, R.: Haltung von Tränkkälbern und Open-field-Reaktivität. Arch. Tierz., Berlin 31 (1988), 35-42

The open-field test as an assessment of the temperament of dairy cows. Anim. Behav. 23 (1975), 615624

KOVALCIKOVA, M.; KOVALCIK, K.; BROUCEK, J.:

The effects of the bull on the reactions and adaptibility of the daughters in behavioural tests. Zivoc. Vyr. 33 (1988), 201-209

KUBEK, A.; TRAKOVICKA, A.; BEZOVA, K.; ZITNY, J.; CELECHOVSKY, M.:

Evaluation of dairy production characteristic of Slovak spotted breed with attention to the specific combining ability of sires of daughters and sires of dams. Acta fytotechnica et zootechnica. 3 (2000), Suppl., p. 142

LE NEINDRE, P.; BOIVIN, X.; BOISSY, A.:

Handling of extensively kept animals. Appl. Anim. Behav. Sci. 49 (1996), 73-81

MANTECA, X.; DEAG, J.M.:

Individual differences in temperament of domestic animals: A review of methodology. Anim. Welf. 2 (1993), 247-268

PETHERICK, J.C.; HOLROYD, R.G.; DOOGAN, V.J.; VENUS, B.K.:

Productivity, carcass and meat quality of lot-fed Bos indicus cross steers grouped according to temperament. Austral. J. Experim. Agric. 42 (2002), 389-398

PUPPE, B.: Wohlbefinden bei Nutztieren: Eine verhaltensbiologische Übersicht. Biol. Zent.bl. 115 (1996), 3-15

REALE, D.; GALLANT, B.Y.; LEBLANC, M.; FESTA-BIANCHET, M.:

Consistency of temperament in bighorn ewes and correlates with behaviour and life history. Anim. Beh. 60 (2000), 589-597

SAMBRAUS, H.H.:

SATO, S.: Applied ethology - it`s task and limits in veterinary practice. Appl. Anim. Behav. Sci. 59 (1998), 39-48

Factors associated with temperament of beef cattle. Jpn. J. Zootech. Sci. 52 (1981), 595-605

SOCH, M.; KOLAROVA, P.; REHOUT, V.; KOSVANEC, K.; HAJIC, F.; CITEK, J.:

Effect of dairy cows moving from tie-stall to loose housing system on their production and behaviour. Sbornik ZF JU Ceske Budejovice - zootechnicka rada. 14 (1997), 77-86

SOCH, M.; KOSVANEC, K.; REHOUT, V.; KADLEC, J.; NOVOTNY, D.:

Comparison of meat performance characteristics of bulls - crossbreeds $F_{1}$ generation of Bohemian Red Cattle Breed x Bohemian Spotted Cattle Breed and bulls Bohemian Spotted Cattle Breed. ZF JU Ceske Budejovice - zootechnicka rada. 15 (1998), 47-56 


\section{STATISTIX FOR WINDOWS:}

User`s Manual. Analytical Software, P.O.Box 12185, Tallahassee, FL 32317-2185, USA, ISBN 1881789-04-7, (1996), $333 \mathrm{p}$.

VOISINET, B.D.; GRANDIN, T.; O'CONNOR, S.F.; TATUM, J.D.; DEESING, M.J.:

Bos Indicus-cross feedlot cattle with excitable temperaments have tougher meat and a higher incidence of borderline dark cutters. Meat Sci. 46 (1997a), 367-377

VOISINET, B.D.; GRANDIN, T.; TATUM, J.D.; O'CONNOR, S.F.; STRUTHERS, J.J.:

Feedlot cattle with calm temperaments have higher average daily gains than cattle with excitable temperaments. J. Anim. Sci. 75 (1997b), 892-896

Received: 2003-08-22

Accepted: 2003-12-12

Corresponding author

Dipl. Ing. JAN BROUCEK, DrSc., PhD.

Forschungsinstitut für Tierzucht

VUZV

Hlohovska 2

94992 Nitra

Slovakia

E-mail: broucek@vuzv.sk 